\title{
HOW TO SPEAK ABOUT IMMIGRANTS AND REFUGEES? QUANTITATIVE AND QUALITATIVE ANALYSIS OF ARTICLES PUBLISHED ON SWEDISH PUBLIC-SERVICE TELEVISION'S NEWS SITE
}

\author{
Maja CHACIŃSKA (University of Gdańsk) \\ ORCID: 0000-0002-2219-6564
}

\section{Introduction}

According to the Swedish Migration Agency (Migrationsverket), in 2015 Sweden received more refugees per capita than any other European country (registered number 181,890 ). In the year of the European immigration crisis, almost 163,000 people sought asylum in this country. ${ }^{1}$ In $2018,{ }^{2}$ there were still over 52,000 people registered entering the country by the Migration Agency. ${ }^{3}$ At the end of 2019, when this article was written, in Sweden, a country with population of a little over 10 million, ${ }^{4}$ almost 2 million inhabitants were born outside the country. ${ }^{5}$ It is obvious that the question of immigration and refugees has received broad media coverage, and it has become a challenge to speak about those issues in the news without prejudice and stereotypes.

1 “Applications for asylum received, 2015," Migration Sverket online, 1 December 2019, https://www.migrationsverket.se/Om-Migrationsverket/Statistik/Asyl.html.

${ }^{2}$ The last year for which statistics are available when this article was written.

3 "Personer boende i Migrationsverkets mottagningssystem, 2018," Migration Sverket online, 1 December 2019, https://www.migrationsverket.se/Om-Migrationsverket/Statistik/Asyl.html.

4 "Sveriges befolkning (Swedish population)," Statistics Sweden (Statistiska centralbyrå) online, 3 December 2019, https://www.scb.se/hitta-statistik/sverige-i-siffror/manniskorna-isverige/sveriges-befolkning/.

5 "Utrikes födda i Sveride (Citizens born outside Sweden)," Statistics Sweden (Statistiska centralbyrå) online, 3 December 2019, https://www.scb.se/hitta-statistik/sverige-i-siffror/manniskorna-i-sverige/utrikes-fodda/. 
In $2016,{ }^{6}$ Swedish public-service television SVT was found guilty by the Swedish Press and Broadcasting Authority when a reporter covering a school attack in Trollhättan municipality described the victims as "not completely Swedish" (inte helsvenska) judging by their appearance (this is how the attacker chose them). ${ }^{7}$ There are other examples of these kinds of cases in which SVT or other stations were found guilty. ${ }^{8}$ In those cases, Swedish Press and Broadcasting Authority based their criticism on a paragraph in Swedish Radio and Television Law that asserts "television's particular impact."

In light of this development, it became clear that the journalists in the publicservice media needed some kind of regulations or guidelines concerning the use of language. In 2015, Anne Lagercrantz, an executive at Swedish public service television's News Division, published an internal document consisting of language advice meant to make the news coverage more inclusive. The advice for the employees included e.g. avoiding generalizations about ethnic groups, areas or religions.

The purpose of this article is to present how the SVT document is applied four years later and what language is used in news articles published on svt.se (public service television's news site). Using elements of media discourse analysis of relevant articles on svt.se from 2019 as well as quantitative analysis, the article will consider the language choices from a cultural and media perspective as well as some relevant themes and contexts. The aim of the quantitative analysis is to research how the recommended words and phrases are used in relation to those that are not recommended. Through qualitative analysis, I would like to explore whether the use of the document helps the quest of inclusion and diversity or if it was just News Division's PR reaction to being penalized.

\section{How It Began}

For the past several years, svt.se has been ranked among the five best news websites in Sweden, ${ }^{10}$ which gives it considerable influence. In the midst of the Migration Crisis on the $16^{\text {th }}$ of December 2015, the head of the News and Sports Division at the Swedish public-service television Sveriges Television, Anne Lagercrantz, wrote on her blog: "Our mission is to reflect the whole Sweden, a changing country. We must make sure that we express ourselves in an inclusive way, even in stressful situations." ${ }^{\prime 11}$ Lagercrantz went on to explain how important but also difficult it was to compile a set of guidelines that would provide guidance for journalists who should use inclusive language in the changing world. At the same time, she found this to be of great significance as she stated: "Language is power. Language is also politics. Language indicates norms."12 Therefore, a document containing advice was linked in Lagercrantz's blog entry and as these words are being written one can find there a revised version from October 2016.

\footnotetext{
${ }^{6}$ The verdict was announced in 2016 but the situation occurred in 2015.

7 "Rapport i SVT fälls för att ha befäst fördomar," Myndigheten för press, radio och tv online, 28 December 2019, https://www.mprt.se/sv/nyhetsrum/pressmeddelanden/2016/rapport-iSVT-falls-for-att-ha-befast-fordomar/.

8 "Kränkande uttalande i TV4," Myndigheten för press, radio och tv online, 28 December 2019, https://www.mprt.se/sv/nyhetsrum/pressmeddelanden/2019/krankande-uttalande-i-tv4/.

${ }_{9}^{9}$ Radio- och tv-lag (2010:696), 4 kap. 9 §, 10.

10 “Topp100 2019: Här är årets 5 bästa nyhetssajter,” Topp100 online, 20 November 2019, https://topp100.idg.se/2.39772/1.715014/topp100-2019-nyheter.

11 Anne Lagercrantz, "Nya språkråd för att bättre spegla hela Sverige," last modified 16 December 2015, https://www.SVT.se/SVT-bloggen/post/nya-sprakrad-att-battre-spegla-hela-sverige/.

${ }^{12} \mathrm{Ibid}$.
} 
It is necessary for the purpose of the analysis in this article to summarize the key content of this 4-page-long document. Its title "Hints and Language Advise When You Work on Reflecting Sweden - Diversity in Focus" ("Tips och språkråd när du jobbar med att spegla Sverige - fokus mångfald") indicates that it does not have an obligatory or regulatory character, but merely an advisory one, and that it emphasizes diversity. The document starts with some general background information concerning what being Swedish means today ("many different appearances, experiences and cultures") ${ }^{13}$ and what the Swedish public-service television approach is: "to cover everybody's daily life." ${ }^{, 14}$ In the next part of these general remarks, the authors use more categorical language and are no longer only advisory. It is stated that journalists will/shall (sw. ska) always consider if revealing a person's ethnic background or appearance is relevant for the news presented. ${ }^{15}$ According to the document, the best solution is, if possible, to let people who are in some way present in the news to define themselves.

Next, a longer part of the document is called Groups. The authors state in the beginning that avoiding generalizations is the main rule that should be applied while describing groups that represent a certain ethnicity, geographical region or religion. Groups that are discussed in this paragraph are Swedes ("everybody with Swedish citizenship" "without further grading who is less or more Swedish), immigrants (a vague designation, "many times used wrongly"17), people born in Sweden or outside Sweden, native, those with a foreign background or foreign roots, those born outside the Nordic region, those born outside Europe (if possible should be used only in statistical reports).

The next part of the document is called "Individuals" and consists only of a short paragraph. The authors state that journalists should avoid classifying people based on their origin. National background should only be mentioned if it is necessary for understanding the reported news even in cases of hate crime. If somebody believes they are a victim because of their roots, the journalist should clarify that it is the victim's perspective ("they believe that they were a victim because of their skin colour"). ${ }^{18}$

The next paragraph is called "Appearance" and mainly discusses the mentioning of skin colour which, according to the authors, is a sensitive and often controversial issue. The authors repeat here that the determining factor should always be the relevance of the descriptor. If possible, people appearing in the news should use their own words to describe their own appearance and words such as "white, black, light-skinned, darkskinned, etc." should be used only if necessary. One should also avoid describing others as "coloured" or "of [an]other skin colour" because those phrases "assume a white norm.","19

The next part of the document describes how SVT's journalists should approach descriptions of city districts. It starts with a statement: "Vulnerable districts are described as immigrant-dense, which means that national background is used as explanatory model for something. ${ }^{, 20}$ The authors of the document name other factors

${ }^{13}$ Tips och språkråd när du jobbar med att spegla Sverige — fokus mångfald, arbetsdokument Sverigespegling version 20161014," SVT Static online, 20 November 2019, http://www.SVTstatic. se/image-cms/SVTse/1476689471/SVT-bloggen/article10673639.SVT/BINARY/Tips\%20och\%20språkråd\%20reviderad\%20oktober\%202016.

${ }^{14}$ Ibid.

${ }^{15}$ Ibid.

${ }^{16}$ Ibid.

${ }^{17}$ Ibid.

${ }^{18}$ Ibid.

${ }^{19}$ Ibid.

${ }^{20}$ Ibid. 
that can be used to explain the situation in deprived areas such as high unemployment rates or low income. The word that should also be avoided in this context is Swedish for "suburbia" (mainly with a definite determiner, equivalents of the English "the" sw. förorten). In the big city context (Stockholm, Göteborg and Malmö), the meaning of förorten can be compared to the American "projects," and some of the former were actually built as part of a housing programme called Million Project (se. Miljonprogrammet) between $1965-1975^{21}$. However, in a different context, the word still just means a suburban area. The authors of the document suggest that using a phrase "socially/economically vulnerable areas" is more suitable if needed. ${ }^{22}$ The last section of the document is a short list including words/phrases with SVT's own definitions and information if and how they can be used. The list consists of just 6 words/phrases: newly arrived (about people, sw. nyanländ), segregated school, refugee, asylum seeker, EU migrants and ethnic/ethnicity. ${ }^{23}$

At the beginning and end of her blog entry, Anne Lagercrantz encouraged SVT employees and people outside the company to comment and participate in discussion about the document described herein. There were some reactions to it in the media, in addition to a special event. In August 2016, Lagercrantz participated in a conversation with a linguist Mikael Parkvall organised by Publicistklubben, a press organization created in 1874 and supporting freedom of expression, ${ }^{24}$ in Stockholm that was followed by a debate on politically correct language with the Swedish Minister of Culture among others. ${ }^{25}$ Swedish public-service television was criticised by the extreme right-wing site Fjälsjö Nyheter ${ }^{26}$ and was accused e.g. of denying existence of ethnic Swedes. ${ }^{27}$ Additional criticism came from the conservative and anti-immigrant site Nyheter idag, which published an article with the title "SVT's Employees Got a New Directive - Terrorists Should Be Called Swedes." ${ }^{28}$ A less radical but also conservative local newspaper Borås Tidning pointed out that the document "Tips och språkråd..." is incompatible with SVT's general policy to increase diversity in its coverage because it encourages journalists to avoid the words that "depict society's ethnic, cultural and religious diversity." 29 There were also some critical remarks on various blogs ${ }^{30}$ but overall the critical reactions on the Internet were fewer than one could expect.

${ }^{21}$ Birgitta Johansson (ed.), Miljonprogrammet - utveckla eller avveckla? (Stockholm: Formas Fokuserar, 2012), 7-9.

22 "Tips och språkråd när..."

${ }^{23}$ Ibid.

24 “Om pk (About us), Publicistklubben online, 27 November 2019, http://www.publicistklubben.se/om-pk/

25 "Laddade ord i medierna," Sveriges Radio online, 27 November 2019, https://sverigesradio.se/sida/artikel.aspx?programid $=1650$ \&artikel $=6505262$

${ }^{26}$ The site was closed.

27 "SVT:s nyheter ska vinklas med eget spark," Fjallsjo online, 27 November 2019, http://www.xn--fjllsj-cua2m.nu/media/20170330-SVTs-nyheter-ska-vinklas-med-eget-sprak-0.php.

${ }^{28}$ Mattias Albinsson, "SVT:s medarbetare făr nya direktiv - Terrorister ska beskrivas som svenskar," last modified 17 December 2015, https://nyheteridag.se/SVTs-medarbetare-far-nyadirektiv-terrorister-ska-beskrivas-som-svenskar/.

${ }^{29}$ Andreas Johansson Heinö, "Heinö: SVT:s språkråd är inget att ta efter,” Boras Tidning online, last modified 21 March 2016, http://www.bt.se/ledare/heino-SVTs-sprakrad-ar-inget-att-ta-efter/

30 "Behöver ni lite folkbildning? Här är en 'Kort ordlista från SVT'," Anybody's Place online, 27 November 2019, http://anybodys-place.blogspot.com/2015/12/behover-ni-lite-folkbildning-har-ar-en.html. 


\section{Analysis}

The analysis material consists of 205 articles from Sveriges Television's news site svt.se including words described as recommended or problematic in the document presented earlier "Tips och språkråd..." Three types of articles are included in the analysis: news articles and analytical articles written by SVT journalists and commentaries. Commentaries are written by experts who are not employed by SVT and therefore a disclaimer is always included: "Opinions in the article are the author's." The articles were published during a four-month period between the $1^{\text {st }}$ of July and the $31^{\text {st }}$ of October 2019 . The length of the period subject to analysis was determined according to the number of articles - 205 is a sufficient number for both quantitative and qualitative analysis for an article of this length. All the articles can be found on the svt.se site. As the links to them are very long, only authors, titles and dates are stated in the footnotes; however, links are provided in the Bibliography. Table 1 presents a summary of the words and phrases used in the analysed articles.

Table 1. Words and phrases used in 205 articles from svt.se.

\begin{tabular}{|l|c|c|}
\hline \multicolumn{1}{|c|}{ Word/Phrase } & $\begin{array}{c}\text { Number in July-October } \\
2019\end{array}$ & Number of articles \\
\hline $\begin{array}{l}\text { immigrant/s (also as a prefix } \\
\text { in Swedish) }\end{array}$ & 49 & 27 \\
\hline born abroad & 59 & 26 \\
\hline suburbia (negative) & 35 & 20 \\
\hline suburbia (neutral) & 6 & 5 \\
\hline vulnerable areas & 104 & 11 \\
\hline foreign background/origin & 23 & 2 \\
\hline other background & 3 & 5 \\
\hline ethnic & 5 & 4 \\
\hline ethnicity & 4 & 17 \\
\hline Swedish citizen & 22 & 9 \\
\hline dark-skinned & 10 & 2 \\
\hline black & 2 & 45 \\
\hline refugee & 137 & 27 \\
\hline newly arrived & 65 & \\
\hline
\end{tabular}

Source: the author's compilation.

As I would like to combine qualitative and quantitative analysis in the next section of this article, I also extracted the main and secondary topics of the discourse on svt.se and assigned each article to one or more of these topic categories. Table 2 presents the main topics and the number of articles assigned to them. 
Table 2 Main topics in discourse on multicultural society.

\begin{tabular}{|l|c|}
\hline \multicolumn{1}{|c|}{ Topic } & Number of articles \\
\hline Crime & 53 \\
\hline Situation in vulnerable areas & 17 \\
\hline Integration/segregation/discrimination & 33 \\
\hline Cost of refugees for the Swedish State and municipalities & 32 \\
\hline Swedish migration policy & 14 \\
\hline Statistics and facts on migration & 15 \\
\hline Unemployment among immigrants and refugees & 19 \\
\hline
\end{tabular}

Source: the author's compilation.

Among the secondary topics connected with multicultural diversity in Sweden, the most often mentioned in the articles analysed were: refugee/immigrant women (11 articles), school and education in deprived areas (9), criminal gangs (9) and racism and prejudice (7).

\section{The People}

As it was shown in Table 1, the descriptor of individuals and groups that was used most often in the text was the word "refugee/s." The word was used 138 times in 46 articles. A similar phrase, describing the same group of people — "newly arrived" - was used 65 times. They were both words/phrases recommended in SVT's guidelines, meaning in Swedish "a person who is escaping" (in Swedish "refugee" and "escape" derive from the same word, sw. flykting, på flykt), which according to the guidelines emphasises the human aspect of the person's situation while the Swedish Migration Agency defines "refugees" only as people who actually received refugee status in Sweden. ${ }^{31}$ As the discourse analysed here concerns Sweden, I did not take into consideration articles that described the situation of refugees in other countries.

Most often the descriptor "refugees/newly arrived" was used in a negative context. The negative aspect in most cases does not, however, concern refugees as people but the cost that the Swedish state and the receiving municipalities need to bear to accommodate and educate the newly arrived ( 22 articles). One example is 6 articles about the situation in the Filipstad municipality. During the Refugee Crisis in 2015, the municipality received the largest number of refugees in proportion to its population. In 2019, Filipstad had the largest number of welfare beneficiaries. ${ }^{32}$ In one of the articles, the author writes that the situation is the result of the refugee flow. But when addressing the large rate of unemployment in the municipality, she writes about "born

\footnotetext{
31 "Tips och språkråd när du jobbar..."

${ }^{32}$ Lina Makboul, "Jim från Filipstad försöker uppvigla kommuner mot staten," SVT Nyheter online, 28 August 2019, https://www.SVT.se/nyheter/granskning/ug/jim-fran-filipstad-forsokeruppvigla-kommuner-mot-staten.
} 
abroad" which may indicate other immigrants than refugees. ${ }^{33}$ In a commentary, the economy professor Mats Hammarstedt calculates that the cost provided by the Swedish state or municipalities for care for one refugee is 190 thousand SEK per year. ${ }^{34}$ Hammarstedt does not put the blame on refugees but on the Swedish state that decided to settle refugees in smaller towns or rural areas with less work opportunities as "a way to keep the countryside alive." 35

The other negative context in which the words "newly arrived" and "refugee" are used in the articles is segregation or lack of integration (9 articles). The greatest number (6) are articles concerning the self-government of the Sölvesborg municipality that refused to accept the allotted number of refugees and proposed placing them in caravans outside the municipality. ${ }^{36}$ The municipality also decided to defy the 2016 Swedish Settlement Law that gives the Migration Agency the right to decide where the refugees with residence would settle down. ${ }^{37}$ The local politicians from Sölvesborg argue in an interview with SVT that the law on municipalities' right to self-govern should override the Settlement Law in such situations. ${ }^{38}$

The positive context in which the words "refugee" and "newly arrived" are mentioned in the texts analysed herein has to do with good examples of integration and integration-oriented activities (13 articles) that include stories of a 2016 Syrian refugee, Gabriel, who now studies medicine at a Swedish university, ${ }^{39}$ two refugees employed at the historic renovations whose qualifications helped to save old stucco details from late $19^{\text {th }}$ century, ${ }^{40}$ and an integration sport project in Lulea during which the refugees are e.g. learning how to skate. ${ }^{41}$ There is also a report from a successful municipality, Storuman, that was active in helping to find employment for many of the newly arrived refugees. $^{42}$

${ }^{33}$ Lina Makboul, “Arbetsförmedlingen: Finns inga jobb för utrikesfödda analfabeter,” SVT Nyheter online, 28 August 2019, https://www.SVT.se/nyheter/granskning/ug/arbetsformedlingen-finns-inga-jobb-for-utrikesfodda-analfabeter.

${ }_{34}$ Mats Hammarstedt, "Uppdrag gransknings reportage borde inte förvåna någon," SVT Nyheter online, 29 August 2019, https://www.SVT.se/opinion/uppdrag-gransknings-reportageborde-inte-forvana-nagon.

${ }^{35}$ Ibid.

36 "Pilotärende när Sölvesborg säger nej till nyanlända," SVT Nyheter online, 14 August 2019, https://www.SVT.se/nyheter/snabbkollen/pilotarende-nar-solvesborg-sager-nej-till-nyanlanda.

${ }^{37}$ Linette Israelsson, "Bengtsfors vill inte ta emot fler nyanlända," Expressen online, 17 September 2019, https://www.expressen.se/gt/bengtsfors-vill-inte-ta-emot-fler-nyanlanda/.

38 "Sölvesborg utmanar bosättningslagen — hör debatten i Aktuellt," SVT Nyheter online, 2

October 2019, https://www.SVT.se/nyheter/inrikes/solvesborg-utmanar-bosattningslagen-hordebatten-i-aktuellt.

39 Linda Asmar, "Efter flykten från Syrien - nu gör Gabriel sitt fjärde år på läkarprogrammet," SVT Nyheter online, 9 September 2019, https://www.SVT.se/nyheter/lokalt/sodertalje/efter-flykten-fran-syrien-nu-gor-gabriel-shamoun-sitt-fjarde-ar-pa-lakarprogrammet.

40 Bosse Carlqvist, "Mustafas kunskaper räddar sekelskiftesrenovering i Skara," SVT Nyheter online, 18 September 2019, https:/www.SVT.se/nyheter/lokalt/vast/mustafaskunskaper-raddar-sekelskiftesrenovering-i-skara.

${ }^{41}$ Elisabeth Lång, "Asylsökande på hal is — testar skridskoåkning för första gången," SVT Nyheter online, 26 July 2019, https://www.SVT.se/nyheter/lokalt/norrbotten/asylsokande-pa-halis-testar-skridskoakning-for-forsta-gangen.

${ }^{42}$ Josefina Kangasharju and Maria Brändström, "Här väljer tre av fyra flyktingar att stanna," SVT Nyheter online, 16 October 2019, https://www.SVT.se/nyheter/lokalt/vasterbotten/harvaljer-3-av-4-flyktingar-att-stanna-kanns-helt-fantastiskt-storuman. 
The word "immigrant" (sw. invandrare) that, according to the SVT's document, should be used with caution, was used 50 times in 27 articles in the period analysed. This is a relatively small number considering that it is a period when the issue is discussed frequently and that the words "refugee" and "newly arrived" are used over 200 times. In the majority of those 27 articles the word "immigrant" is used as a quotation (17), and three times it is the immigrants' self-description. SVT quotes, among other sources, reports and research, ${ }^{43}$ politicians ${ }^{44}$ and citizens. ${ }^{45}$ Immigrants who describe themselves or other immigrants with the Swedish word invandrare are e.g. Zlatan Ibrahimovic (two articles on the football player's critique of the Swedish coach for not choosing more players of an immigrant background) ${ }^{46,47}$ and there is also a name of an immigrant organisation (Invandrarnas samorganisation) that took a stand in a debate on the quality of Swedish language education for immigrants. ${ }^{48}$

This debate was actually one of the main topics in which the word "immigrant" was used (12 articles). It was mainly due to a political discussion on setting limitations and stricter requirements concerning immigration to Sweden. One of the political parties proposed limited access to interpreters for immigrants who, after a longer period of time, still do not speak Swedish. ${ }^{49}$ This in turn triggered a discussion on changes in approaches to teaching Swedish to immigrants. Ulf Kristersson, party leader of Moderaterna (centre-conservative, main opposition party) argued that there should be more requirements during the Swedish language courses for immigrants than just attendance. ${ }^{50}$ There were also three articles that described clearly racist or xenophobic attitudes. Two concerned the same issue, dismissal of the head of Södertälje science park for his racist remarks on immigrants from Africa and the Middle East ${ }^{51,52}$, and one

${ }^{43}$ Susanna Ahnlund, "Specialutbildade elever på Bäckby ska sprida kunskap om naturens hälsofördelar," SVT Nyheter online, 23 October 2019, https://www.SVT.se/nyheter/lokalt/ vastmanland/testa-dina-naturkunskaper-med-elever-fran-backbys-nya-pilotprojekt.

${ }^{44} \mathrm{Ki}$ Andersson, "Tre politikområden i fokus för Moderaterna," SVT Nyheter online, 19 October 2019, https://www.SVT.se/nyheter/inrikes/tre-politikomraden-i-fokus-for-moderaterna.

45 David Boati, "Släkting sa upp bekantskapen efter diskussion om invandring," SVT Nyheter online, 17 Septmeber 2019, https://www.SVT.se/nyheter/inrikes/slakting-sa-uppbekantskapen-efter-diskussion-om-invandring.

${ }^{46}$ Carl Sköldbäck and Louv Brattgård, "Zlatan nekar till faktafelet: 'Är du säker?,," SVT Sport online, 8 October 2019, https://www.SVT.se/sport/fotboll/zlatan-nekar-till-faktafelet-ardu-saker.

${ }^{47}$ Max Schüllerqvist, "Zlatan: 'Han förstör det jag byggt upp i 20 år'," SVT Sport online, 8 October 2019, https://www.SVT.se/sport/fotboll/han-forstor-det-jag-byggt-upp-i-20-ar.

48 Winnie Gravlund, "Invandrarnas samorganisation: Börja med att se över sfi," SVT Nyheter online, 14 October 2019, https:/www.SVT.se/nyheter/lokalt/helsingborg/helt-fel-vagatt-ga-om-fler-ska-lara-sig-svenska.

${ }^{49}$ Winnie Gravlund, "Begränsad rätt till tolk i Helsingborg utreds — kan vara lagbrott," SVT Nyheter online, 14 October 2019, https://www.SVT.se/nyheter/lokalt/helsingborg/nu-utredsbegransad-ratt-till-tolk-i-helsingborg-kan-bli-ett-lagbrott.

${ }^{50}$ Mikael Klintevall, "Ulf Kristersson (M): Begränsa rätten till tolkhjälp," SVT Nyheter online, 1 July 2019, https://www.SVT.se/nyheter/inrikes/presstraff-med-ulf-kristersson-i-almedalen.

${ }_{51}$ Omar Daham, Linda Asmar, and Maja Flygt, "Ordförande Leif Östling lämnar Södertälje science park efter kritiserat uttalande," SVT Nyheter online, 31 October 312019 , https://www.SVT.se/nyheter/lokalt/sodertalje/leif-ostling-lamnar-sodertalje-science-park.

${ }_{52}$ Karin Fallenius, "Östling intervjuades av sajt med kopplingar till vit makt-miljö Godner (S) kritisk," SVT Nyheter online, 30 October 2019, https://www.SVT.se/nyheter/ lokalt/sodertalje/leif-ostling-stallde-upp-i-intervju-pa-sajt-med-kopplingar-till-vit-makt-miljon. 
was a commentary article about Sverigedemokraterna — a Swedish right-wing populist and anti-immigrant party. ${ }^{53}$

There are only four articles in which the word "immigrant" is mentioned in a positive light, just as in the case of the word "refugees" in the context of good practice integration. Those include a story of an 83-year old Kjell Stevander who has a muscle illness and loves his home care assistants "almost all of them immigrants [...] wonderful guys. " ${ }^{, 54}$ Another example is a project that is being implemented in Bäckby. The project involves teaching immigrants a healthy lifestyle close to Swedish nature and trying to diminish the health gap between native Swedes and immigrants. ${ }^{55}$

Another phrase used to describe immigrants in these texts is "born abroad" (utrikesfödda) which, according to SVT, can be used if it is necessary to show a difference e.g. in statistics. ${ }^{56}$ As shown in Table 1, the phrase was used 59 times in 26 articles in the period analysed and again the majority of the articles put "born abroad" in a negative context (17 articles). The phrase was used as recommended in statistics (17 articles) but they mostly relate to unemployment among people born outside Sweden compared to those born in Sweden (16 articles). ${ }^{57}$ Seven of those articles concern women: "For the first time since 2011 [the] unemployment rate is equal among men and women." 58 Women who are unemployed are mainly born abroad and have very little or no education; in one article it is even stated that some of them are "illiterate" (a quote from an Unemployment Office clerk). ${ }^{59}$

\section{The Places}

As described earlier, the Swedish word "suburbia" was considered by SVT News Division as particularly negatively charged, and journalists were advised not to use it in the meaning of "problem areas." The word "suburbia" is used only 37 times in 21 articles while the recommended phrase "vulnerable areas" is used 104 times in 43 articles. In all the articles the word förorter ("suburbia") has a pejorative overtone, including when used by the ones who live there. The suburban districts are presented as places where crime is booming and where the residents have fewer opportunities; for example "people are shot to death in our suburbia," 60 "when you live in suburbia your

\footnotetext{
${ }^{53}$ Salam Karam, "Om SD inte är främlingsfientligt — vad är då främlingsfientlighet, enligt Sveriges Radio?,” SVT Nyheter online, 22 October 2019, https://www.SVT.se/opinion/om-sdinte-ar-framlingsfientligt-vad-betyder-da-framlingsfientlighet-enligt-sveriges-radio.

${ }^{54}$ Joel Sund, "Muskelsjuka Kjell älskar hemtjänsten: 'Det är änglar allihopa'," SVT Nyheter online, 28 September 2019, https://www.SVT.se/nyheter/lokalt/vast/muskelsjuka-kjell-alskarhemtjansten-det-ar-anglar-allihopa.

${ }_{55}$ Susanna Ahnlund, "Specialutbildade elever på Bäckby ska sprida kunskap om naturens hälsofördelar," SVT Nyheter online, 23 October 2019, https://www.SVT.se/nyheter/ lokalt/vastmanland/testa-dina-naturkunskaper-med-elever-fran-backbys-nya-pilotprojekt.

56 "Tips och råd..."

${ }^{57}$ Lina Makboul, "Alex Schulman: Aldrig sett en kommunperson så nedslagen," SVT Nyheter online, 28 August 2019, https:/www.SVT.se/nyheter/granskning/ug/alex-schulmanaldrig-sett-en-kommunperson-sa-nedslagen.

58 "Män och kvinnor lika arbetslösa," SVT Nyheter online, 15 July 2019, https://www.SVT.se/nyheter/snabbkollen/man-och-kvinnor-lika-arbetslosa.

${ }^{59}$ Lina Makboul, "Arbetsförmedlingen...."

${ }^{60}$ Lotta Zachrisson, "Mikael Damberg: 'Vi bjuder in alla partier utom SD till samtal'," SVT Nyheter online, 1 September 2019, https://www.SVT.se/nyheter/inrikes/debatt-ulf-kristersson-moch-mikael-damberg-s-om-gangvaldet.
} 
role models are criminals," ${ }^{61}$ "the only free market that works for people in the suburbia is drug dealing." ${ }^{\circ 2}$ However, it should be added that these descriptions are not SVT's journalists but quotes from others. Even when some good practice is described, the word "suburbia" has a negative connotation, one example being a project leader who says "many girls in the suburbs felt 'invisible,.",63

In 28 articles, when the phrase "vulnerable area" is used it is in connection with crime. However, it is more relevant for this analysis that "vulnerable areas" are not directly connected or combined in those articles with immigrants or refugees. The phrase is used in connection to immigrants only in one commentary article in which the author writes: "Vulnerable areas did not happen by accident, but they were created by a political decision. Well, how did it happen that those residential districts with immigrant inhabitants, high unemployment rate, low income, social problems and high crime rate were created?",

The word "immigrant" is also not the only descriptor of the areas in this article. The quote shows that the author adds all the other relevant characteristics recommended in SVT's document. Other instances when there may be some association of the problematic areas with immigrants can be found in 4 of 43 articles. In an article from August, the author presents a research project on the influence of Salafism (the orthodox form of Islam) in Sweden. It is stated that the researchers will "look at the areas that the police calls vulnerable or particularly vulnerable." ${ }^{65}$ This statement can indicate that those areas are populated by immigrants or children of immigrants as the ethnic Swedes are mostly Christian. ${ }^{66}$ The statement can be considered a quotation as it is a description of the project.

Another article that in an indirect way can be perceived as connecting "vulnerable areas" with immigrants is an article about schools in those areas. The interviewed children's names, Sara Taleb and Delan Ahmed, do not sound typically Swedish but this can be of course considered a vague connection. ${ }^{67}$ In two articles the words "segregation" and "integration" are used in regard to problematic areas. One of those articles is an interview with Swedish prime minister, Stefan Löfven, who speaks about crime prevention in problematic areas without making any reference to immigrants. When the prime minister says that young boys should go to school and see their parents go to work, the journalist asks: "Is this [unemployment] [the result of] an unsuccessful

${ }^{61}$ Petter Ljunggren, "Socialtjänsten placerade Hassan hos kriminell med långt brottsregister," SVT Nyheter online, 18 September 2019, https://www.SVT.se/nyheter/granskning/ug/socialtjanstenplacerade-hassan-hos-kriminell-med-langt-brottsregister.

${ }^{62}$ Philip O’Connor, "Samhället är uppbyggt på att dessa poler hålls åtskilda," SVT Nyheter online, 4 July 2019, https://www.SVT.se/opinion/hela-vart-samhalle-ar-uppbyggt-pa-att-halladessa-poler-atskilda.

${ }^{63}$ Lisa Johansson, "Krabbfiske - en av många vägar till förortstjejernas integration," SVT Nyheter online, 19 July 2019, https://www.SVT.se/nyheter/lokalt/vast/krabbfiske-en-av-mangavagar-till-forortstjejernas-integration.

${ }^{64}$ Peter Sundgren, "Utsatta områden har inte tillkommit av en slump," SVT Nyheter online, 7 July 2019, https://www.SVT.se/opinion/utsatta-omraden-har-inte-tillkommit-av-en-slump.

65 Amanda Gustafsson, "Projekt ska granska salafism i Sverige," SVT Nyheter online, 5 August 2019, https://www.SVT.se/nyheter/lokalt/vast/projekt-ska-granska-salafism-i-sverige.

${ }^{66}$ Erika Willander, Sveriges religiösa landskap - samhörighet, tillhörighet och mångfald under 2000-talet, (Stockholm: Myndigheten för stöd till trossamfund 2019), 35.

${ }^{67}$ Lovisa Blomberg, "Högstadieelever i Vivalla: 'Hade velat gå kvar'," SVT Nyheter online, 17 September 2019, https://www.SVT.se/nyheter/lokalt/orebro/hogstadieelverna-i-vivalla-hadevelat-ga-kvar. 
integration policy?"68 Löfven answers the question without any indication that he is speaking about immigrant families. The tactics used here by Stefan Löfven can be political correctness, but it is also called "obfuscation" or "concealment" (Swedish mörkläggning) in literature. ${ }^{69}$ In this case it would refer to obfuscation of the consequences of immigration by the prime minister. I will come back to this issue in the Conclusions.

The word "segregation" is used in one article in connection to "vulnerable areas" as a quote. In the article, SVT writes about a governmental plan to fight gang crime, and, under the text, the whole 34-clause plan is listed. Clause 28 of the plan states: "Invest long term in schools and social services in the socially vulnerable areas. The work against segregation [...] will be considerably strengthened under this government." ${ }^{, 70}$ However, it should be noted that in the context of this plan, segregation does not directly point to divisions between nationalities but can indicate more general social status.

\section{Other Sensitive Words and Phrases}

As shown in Table 1, the words "ethnic" and "ethnicity" are almost non-existent in the SVT's articles in the period analysed. They are not used many times and when they occur they are quotes, for example: "We are many women with a different background than ethnic Swedish." 71 Only in one case the words "ethnic" and "ethnicity" were used to describe a positive situation — a Diversity Parade organised in Ängelholm, a town in south Sweden. ${ }^{72}$ Other contexts are clearly negative - discrimination, segregation, lack of diversity, demands to limit immigration and racial profiling in the media. ${ }^{73}$

The words "dark-skinned" are used only in quotes and once in a description of a missing child. ${ }^{74}$ The word "black" in regard to skin colour is used only twice and both times describing situations not connected with Sweden, ${ }^{75,76}$ which will be further

${ }^{68}$ Hedvig Eriksson and Mats Knutson, "Löfven: Unga pojkar ska vara i skolan," SVT Nyheter online, 30 August 2019, https:/www.SVT.se/nyheter/inrikes/statsminister-stefan-lofvenom-valdsspiralen.

69 Karl-Olov Arnstberg and Gunnar Sandelin, Invandring och mörkläggning. En saklig rapport från en förryckt tid (Stockholm: Debattförlaget 2014), 41.

70 Jonas Lövfenberg, "Regeringen svarar på avhoppen med eget åtgärdsprogram," SVT Nyheter online, 21 September 2019, https://www.SVT.se/nyheter/inrikes/regeringen-svarar-paavhoppen-med-eget-atgardsprogram.

${ }^{71}$ Ksanet Habte, "Ksanet Habte: Varför får inte vi plats i den här debatten?," SVT Nyheter online, 16 August 2019, https://www.SVT.se/opinion/ksanet-habte-varfor-far-inte-vi-plats-i-denhar-debatten.

72 Maria Pettersson, "Mångfaldsparaden tågade genom Ängelholm," SVT Nyheter online, 31 August 2019, https://www.svt.se/nyheter/lokalt/skane/mangfaldsparaden-tagade-genom-angelholm.

${ }^{73}$ Lydia Farran-Lee, "Granskningnämnden fäller inslag om rasprofilering i TV4: 'Uppenbart kränkande'," SVT Nyheter online, 16 September 2019, https://www.svt.se/kultur/granskningnamnden-faller-inslag-om-rasprofilering-i-tv4.

${ }_{74}$ Amanda Gustafsson and George Adam, "Polisen sökte efter försvunnen årig pojke i Göteborg," SVT Nyheter online, 15 July 2019, https://www.svt.se/nyheter/lokalt/vast/polisensoker-efter-forsvunnen-9-arig-pojke-i-goteborg.

${ }^{75}$ Fanny Renman, "Poliskvinnan sköt hans bror — fick kram i rätten," SVT Nyheter online, 3 October 2019, https://www.svt.se/nyheter/utrikes/hon-skot-hans-bror-ville-krama-henne-i-ratten.

${ }^{76}$ Ylva Larsson, "Kvinnliga politiker sluter upp bakom Meghan: 'Vi står vid din sida'," SVT Nyheter online, 20 October 2019, https://www.svt.se/nyheter/utrikes/kvinnliga-politiker-sluterupp-bakom-meghan-vi-star-vid-din-sida. 
commented on in the Conclusions. The last sensitive phrase that is used in SVT's article on immigration and diversity is "Swedish citizen." In SVT's guidelines this phrase should be used only if it has some legal relevance, otherwise journalists should write about "Swedes" (svensk, svenskar). Among situations in which journalists usually state the citizenship of victims or/and perpetrators like catastrophes that happen abroad (earthquakes and hotel fires), terrorist attacks are also mentioned in the SVT document: "In cases that refer to terrorism, wordings similar to the following can be used: 'Swede who has been associated with violent/militant Islamists'., "77

As shown in Table 1, the phrase "Swedish citizen" is used relatively seldom in the texts analysed herein, namely 22 times in 17 articles. The main topic of all those articles is crime outside Sweden committed by Swedish citizens. Six of them concern terrorism and one concerns a doctor who is a Swedish citizen, facing capital punishment in Iran. ${ }^{78}$ In eight cases the word svensk, meaning "Swede" or "Swedish person," was used in the articles prior to "Swedish citizen," including in the titles of articles, for example, "Swedish woman arrested for terror crime",79 or "Swedes arrested for murder attempt in Finland." ${ }^{\prime \prime 0}$ In most cases it is rather impossible to discern if the phrase "Swedish citizen" refers to ethnic Swedes, people born in Sweden or people born outside Sweden. In one case there is an association with Nigeria, but it is still too little to say that the suspects with Swedish citizenship named in the article are Nigerian Swedish: "Among 15 prosecuted only one woman and one man are Swedish citizens. Many of the prosecuted men have, according to the prosecutor, connections with an occult brotherhood Black Axe — a mafia-like organization with roots in Nigeria." ${ }^{\prime 81}$

\section{Conclusions}

Analysis of the documents shows that SVT's journalists and editors seem to act in accordance with the document written in 2015 (revised in 2016). The word "immigrant" (invandrare) is used rarely compared to other descriptors, and mostly in quotes. Analysis also shows that the word is used pejoratively even if the speakers use it to talk about themselves. It is often connected with difficulties, e.g. "difficulties to find job for immigrants" $\$ 2$ and with difficulties to find consensus about new immigration policy, with integration and racism. Limiting the use of the word in the SVT's reporting and coverage does seem to limit the misuse of it, meaning using it to describe people who are first or second generation born in Sweden. The result that was also achieved by limiting the use of the word to its actual meaning is the disconnection of immigration and crime. The question is whether by doing so SVT is trying to hide an

\footnotetext{
77 "Tips och språkråd..."

78 "Uppgift: Svenskiransk forskare kan stå inför avrättning," SVT Nyheter online, 2 August 2019, https://www.svt.se/nyheter/utrikes/uppgift-djalali-kan-sta-infor-avrattning.

79 "Svensk kvinna gripen för terrorbrott," SVT Nyheter online, 5 July 2019, https://www.svt.se/nyheter/utrikes/svensk-kvinna-gripen-misstankt-for-terrorbrott-pa-flygplats-ilondon.

${ }^{80}$ Andreas Söderlund, "Svenskarna häktas för mordförsök i Finland," SVT Nyheter online, 29 August 2019, https://www.svt.se/nyheter/utrikes/svenskarna-infor-ratta-i-finland.

${ }^{81}$ Helena Jönsson, "Åklagaren: Ostraffad kvinna nyckelspelare i massiva knarkhandeln," SVT Nyheter online, 9 October 2019, https://www.svt.se/nyheter/lokalt/vast/huvudprofilen-iknarkatalet.

${ }^{82}$ Gustaf Hallin, “Avesta kommun vill få fler företag att anställa nyanlända: 'Går miste om kompetens'," SVT Nyheter online, 7 August 2019, https://www.svt.se/nyheter/lokalt/ dalarna/avesta-jobbar-med-projekt-for-att-forandra-attityden-kring-nyanlanda-inom-kommunen.
} 
actual connection. As presented in Table 3, there has been a substantial increase in the number of suspects with one or two immigrant parents and in the number of those born abroad.

Table 3. Share of suspects for all crime.

\begin{tabular}{|c|c|c|c|c|}
\hline & $\begin{array}{c}\text { Not registered } \\
\%\end{array}$ & $\begin{array}{c}\text { Born abroad } \\
\%\end{array}$ & $\begin{array}{c}\text { Born in Sweden } \\
\text { at least one } \\
\text { parent born } \\
\text { abroad \% }\end{array}$ & $\begin{array}{c}\text { Born in Sweden } \\
\text { with two } \\
\text { Swedish parents } \\
\%\end{array}$ \\
\hline $1985-1989$ & 3 & 14 & 14 & 68 \\
\hline $1997-2001$ & 7 & 19 & 19 & 55 \\
\hline $2002-2006$ & 10 & 23 & 17 & 51 \\
\hline $2013-2017$ & 13 & 24 & 21 & 42 \\
\hline
\end{tabular}

Source: Patrik Engellau. Invandring och brottslighet - ett trettioårsperspektiv. Det goda samhället, Stockholm: 2019.

On the other hand, Swedish criminologists state that people born outside Sweden and their children are overrepresented in crime suspect statistics due to discrimination in the judicial system, factors related to their country of origin (wars and conflicts, for example) as well as factors related to living conditions in Sweden (e.g. poverty, social isolation, low economic status). ${ }^{83}$ One should also remember that those statistics do not show that crime increases with an increase in immigration (for example the number of crime related deaths was much higher in Sweden in the 1980s and 1990s, then in 2017). ${ }^{84}$ In light of the complexity of the correlations of crime and immigrants and a variety of interpretations of statistical data it can be considered appropriate for SVT to be hesitant to put the two together. This reluctant approach also applies to connecting immigrants and refugees with problem areas. As was shown in the analysis, the phrase "vulnerable areas" (utsatta områden) was used over 100 times in the period analysed but rarely described areas inhabited by immigrants or refugees. The term utsatt område was created by Swedish police and is described by them as "[a] vulnerable area [which] is a geographically delimited place that is characterised by low socioeconomic status and influence of criminals on the local community. In those areas there is a range of risk factors such as unemployment, illness and unsuccessful education that can result in a lack of faith in the future." 8

It can be stated that SVT uses this phrase in accordance with the police's definition and the main descriptor in the texts analysed is crime connected with the risk factors listed in the definition. However, it can also be claimed that it is only a question of terminology, as a Swedish person can easily make a connection between those areas

83 Jerzy Sarnecki, "Kriminalitet," Migrations Info online, 29 December 292019 , https://www.migrationsinfo.se/valfard/kriminalitet/.

${ }^{84}$ Jonas Öberg and Klara Hradilova Selins, Dödligt våld i Sverige 1990-2017. Omfattning, utveckling och karaktär. Rapport 2019:6 (Stockholm: Brottsförebyggande rådet, 2019), 23.

${ }^{85}$ Utsatta områden - Social ordning, kriminell struktur och utmaningar för polisen. (Stockholm: Nationella operativa avdelningen, 2017), 4. 
and their inhabitants. The Swedish police regularly publish lists of those districts and the media republish it. SVT also published such a list in the period analysed. ${ }^{86}$ The goal with using this phrase instead of the word "suburbia" was that, in Swedish, the latter is immediately associated with immigrants. The question is if this is also not becoming the case with the phrase "vulnerable areas." Either way, the analysis of this article clearly shows that SVT journalists cannot be accused of indicating that this relation (immigrants - vulnerable areas) exists.

The fact that SVT does not connect high crime rate areas with immigrants or the word "immigrant" with the word "crime" does not mean that the SVT's News Division tries to maintain politically correct positivity while describing situation of those people. As shown in the analysis and illustrated in Graphs 1 and 2, the majority of the articles about immigrants and refugees or the newly arrived have a negative tone. This is, however, mainly connected with unemployment and the financial problems of municipalities that refugees have been allocated to, not with crime.

Graph 1.
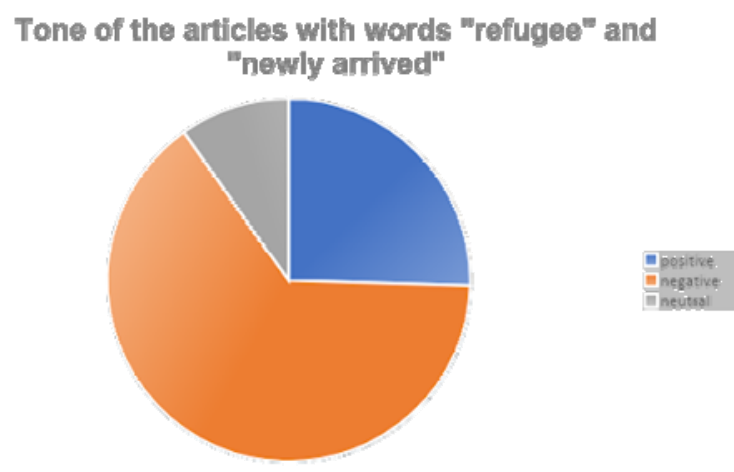

Graph 2.

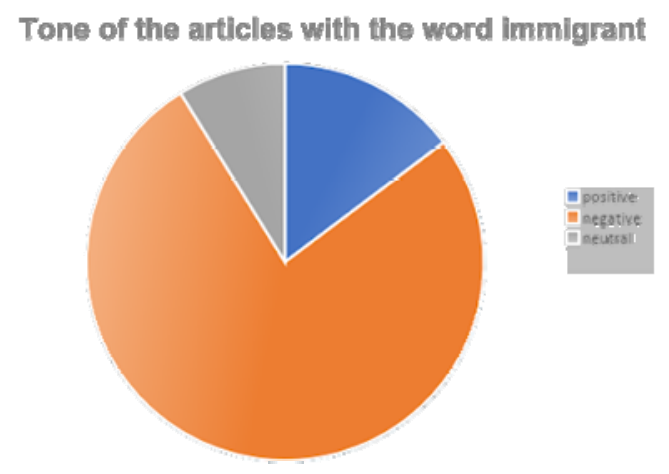

${ }^{86}$ Mats Hedström, "Narkotikahandel och utpressning skakar Jordbro centrum," SVT Nyheter online, 29 October 2019, https://www.svt.se/nyheter/lokalt/stockholm/polisen-oroad-for-utvecklingeni-jordbro. 
The articles characterized as "neutral" presented mainly statistics concerning the number of immigrants or refugees, the increasing Swedish population due to the refugee crisis, and one article concerned a Swedish virtual exhibition about refugee camps in Southern Europe.

In 2013, the Swedish political science professor Henrik Ekengren Oscarsson coined the phrase opinion corridor (åsiktskorridor), describing Swedish mainstream media's politically correct culture. ${ }^{87}$ One of the views that was then according to Oscarsson outside the corridor was that "four of ten Swedes believe that Sweden should accept fewer refugees." ${ }^{\prime 8}$ It can be stated with certainty after analysing the articles that the opinion that Sweden should receive less refugees or immigrants found its place within the SVT's opinion corridor. This issue is mentioned or discussed in 14 articles. It shows that no matter how politically correct the Swedish public service media wants to be, the situation in the country can change this approach.

A similar theory (or hypothesis) also mentioned in this article is that some facts connected to immigration undergo obfuscation. It could be claimed that by not connecting negative phenomena like crime or unemployment with immigration SVT conceals the consequences of said immigration. However, SVT does write about it, as in the aforementioned interview with Prime Minister Löfven when the journalist asks about the connection between the high unemployment rate and integration policy. In this case, it is the politician who avoids associating the two, not the journalist. I also doubt if Löfven does it to obfuscate the truth about immigration. It is more likely that he does not use certain phrasing for political reasons relating mostly to the image of himself and his government.

The two articles in which the word "black" (svart) was used were included in this paper's analysis despite the fact that they did not describe the situation in Sweden. It was done to illustrate in what context this word is used by SVT as a descriptor of skin colour. The first article is about an incident in Dallas in which a policewoman probably accidentally shot an innocent black man. She went into his apartment believing it was hers and shot him to death ${ }^{89}$. The second article was about Meghan Duchess of Sussex and it stated she "is American and has a black Mom and a white Dad." 90 In both cases the information about skin colour is important — in the first article it turns out that the policewoman was spreading racist opinions on her social media and in the second case Princess Meghan was also a target of racism due to her background. It is interesting, however, that SVT does not use the term "African American" which Princess Meghan uses herself when describing her mother's origin, ${ }^{91}$ which would be in accordance with the guideline that people should describe themselves. ${ }^{92}$ It is actually advised in "Tips och språkråd..." "to combine the word Swedish with the person's origin nationality for

${ }^{87} \mathrm{He}$ defined it as the opinion corridor - that is, the buffer zone where you still have some turning space to express an opinion without having to receive a diagnosis of your mental state - is very narrow in Sweden. It is enough today to say that one believes in God (which $45 \%$ of the population says they do) to be regarded as not at the full use of one's mind. Henrik Ekengren Oscarsson, "Väljare är inga dumbommar," Henrik Oscarson online, 10 December 2013, https://www.henrikoscarsson.com/2013/12/valjare-ar-inga-dumbommar.html.

${ }^{88}$ Ibid.

${ }^{89}$ Fanny Renman, "Poliskvinnan sköt hans bror..."

${ }^{90}$ Ylva Larsson, "Kvinnliga politiker sluter upp bakom Meghan..."

${ }^{91}$ Meghan Markle, "Meghan Markle: I'm More Than An 'Other'," Elle online, 22 December 2016, https://www.elle.com/uk/life-and-culture/news/a26855/more-than-an-other/.

92 "Tips och språkråd..." 
example Somali Swedish. ${ }^{93}$ However, the use of the word "black" does not seem to be a problem when it is used to describe the American context.

As mentioned at the beginning, the criticism of "Tips och språkråd..." included the accusation that by not using phrases like "ethnic Swedish" SVT denies multicultural diversity in Sweden. The attempt to exclude some words considered discriminating had already been a practice in Sweden, introduced by the Swedish government. It had been discussed for some time, when in 2014 the Swedish Minister of Integration, Erik Ullenhag, announced the creation of a commission that would prepare to remove the word "race" from Swedish law due to the knowledge that "different human races do not exist." "94 The proposal was criticised by African Swedes Association which asserted that the word was important in the discussion on discrimination. ${ }^{95}$ In 2015, the Commission wrote a report in which it proposed to replace the word "race" with "perception/notion of race" in Criminal Law and the Freedom of Press Act. ${ }^{96}$ The word was earlier (2008) excluded from Swedish Antidiscrimination Act and replaced with the word

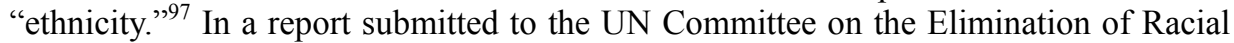
Discrimination, Sweden states that "the actual protection against discrimination has not been watered down by the fact that the Discrimination Act does not use the word 'race'. This particularly applies in the light of the fact that the definition of the ground for discrimination of ethnicity not only includes 'national or ethnic origin' and 'skin colour,' but also 'other similar circumstance'., 98

However, even if from the biological point of view there is only one human race, one can still argue that it is impossible to talk about racism if the term "race" does not exist in the law. Besides, the fact that science does not support the existence of the phenomena does not eliminate the descriptive use of it. So even if the Swedish government does not want to legitimise the word, which in relation to humans is not true, not using it can hide the problem of racism. ${ }^{99}$

The previously mentioned critique of SVT's document may imply that in their guidelines SVT's News Division goes a step further and wants to eliminate the word "ethnic." However, SVT clearly states that it is not to be used to categorize Swedish citizens as ethnically Swedish or not. It is also clear from the articles analysed herein that words "ethnic" and "ethnicity" are used in connection with discrimination, so the guidelines do not eliminate its use but limits it to relevant cases. Putting the issue of ethnicity in a broader theoretical framework, it can be stated that Swedish legislators,

93 Ibid.

94 Ulf Hambraeus, "Rasbegreppet ska bort ur lagen," SVT Nyheter online, 30 July 2014, https://www.svt.se/nyheter/inrikes/rasbegreppet-ska-bort-ur-lagen.

95 Ibid.

96 "Ett utvidgat straffrättsligt skydd för transpersoner m.m.," Betänkande av Utredningen om transpersoners straffrättsliga skydd m.m., SOU 2015:103 (Stockholm 2015), 49, 51.

97 Exactly: "ethnic belonging," sw "etnisk tillörighet," in: Diskrimineringslagen 2008: 567. On this critique:

${ }^{98}$ Consideration of reports submitted by States parties under article 9 of the Convention Twenty-second and twenty-third periodic reports of States parties due in 2016, online, 22 December 2019, https://www.refworld.org/cgi-bin/texis/vtx/rwmain?page= country\&docid=597 89f3f4\&skip $=0$ \&publisher $=$ CERD\&coi $=$ SWE\&querysi $=\% 20$ Sweden\&searchin=fulltext\&sort $=$ date.

99 The Swedish critics of the word "race" propose the use of word xenophobic instead of racist. In Sweden a domestic word is used instead of the Greek-originated främlingsfientlig which means hostile towards strangers. E.g. "Får man säga "förorten"? Se \#pkdebatt om politiskt korrekt språk Del 1, YouTube online, 28 December 2019, https://www.youtube. com/watch?v=bhveFcVdFrc. 
politicians and journalists want to avoid the perception of the nation as "formed on the basis of pre-existing ethnie and ethnic ties, ${ }^{, 100}$ and by this avoid also a notion of the nation, "one that emphasized elements like genealogy, populism, customs and dialects, and nativism" 101 in the multicultural and multi-ethnic society.

In the SVT document it is stated that "it is important that we express ourselves in an inclusive way." ${ }^{, 102}$ It was not the aim of this article to find out if this kind of language helps integration, but it can be argued that it does not strengthen segregation. It does not seem to mask the problems with integration considering for example the great number of articles that in 2019, four years since the immigration crisis, describe the problem with unemployment among refugees and the great cost that the Swedish state bears helping them. The pessimistic tone of the articles as illustrated by Graphs 1 and 2 does not confirm the accusations of political correctness, either.

In conclusion, it can be stated that the quantitative analysis conducted in this article shows that the journalists of svt.se adhere to the document created in 2015 in their language choices. It can then be affirmed that the guidance was created with the purpose of improving the communication and not as a PR gesture. Meanwhile, the qualitative analysis shows that journalists and editors try to use the words "immigrant," "refugee," and "Swedish citizen" in their actual meaning and also construct a neutral perception of immigrants and refugees in Sweden as well as destigmatise the word "suburbia." This approach may in turn contribute to a more inclusive and diverse perception of Swedish society, but it is difficult to conclude if it will actually contribute to diversity and inclusiveness.

\section{BIBLIOGRAPHY}

Ahnlund, S. "Specialutbildade elever på Bäckby ska sprida kunskap om naturens hälsofördelar." SVT, October 23, 2019, https://www.svt.se/nyheter/lokalt/vastmanland/testa-dina-naturkuns kaper-med-elever-fran-backbys-nya-pilotprojekt.

Albinsson, M. "SVT:s medarbetare får nya direktiv - Terrorister ska beskrivas som svenskar." Fjällsjö Nyheter December 17, 2015, https://nyheteridag.se/svts-medarbetare-far-nyadirektiv-terrorister-ska-beskrivas-som-svenskar/.

“Applications for asylum received 2015." Swedish Migration Agency. Accessed December 29, 2019. https://www.migrationsverket.se/Om-Migrationsverket/Statistik/Asyl.html.

Arnstberg, Karl-Olov, and Gunnar Sandelin. Invandring och mörkläggning. En saklig rapport från en förryckt tid. Stockholm: Debattförlaget, 2014.

Asmar, L. "Efter flykten från Syrien — nu gör Gabriel sitt fjärde år på läkarprogrammet." SVT, September 9, 2019, https://www.svt.se/nyheter/lokalt/sodertalje/efter-flykten-fran-syrien-nugor-gabriel-shamoun-sitt-fjarde-ar-pa-lakarprogrammet.

"Behöver ni lite folkbildning? Här är en 'Kort ordlista från SVT'." Anybody's Place. Accessed November 27, 2019. http://anybodys-place.blogspot.com/2015/12/behover-ni-lite-folk bildning-har-ar-en.html.

"Bengtsfors vill inte ta emot fler nyanlända." SVT, September 17, 2019, https://www.svt.se/ nyheter/lokalt/vast/bengtsfors-vill-inte-ta-emot-fler-nyanlanda.

Blomberg, L. "Högstadieelever i Vivalla: 'Hade velat gå kvar'.” SVT, September 17, 2019, https://www.svt.se/nyheter/lokalt/orebro/hogstadieelverna-i-vivalla-hade-velat-ga-kvar.

${ }^{100}$ Anthony D. Smith, The Ethnic Origins of the Nations (Victoria: Blackwell Publications 1988), 137.

$$
{ }^{102} \text { "Ibid. }
$$


Boati, D. "Släkting sa upp bekantskapen efter diskussion om invandring." SVT, September 17, 2019, https://www.svt.se/nyheter/inrikes/slakting-sa-upp-bekantskapen-efter-diskussion-ominvandring.

Carlqvist, B. "Mustafas kunskaper räddar sekelskiftesrenovering i Skara.” SVT, September 18, 2019, https://www.svt.se/nyheter/lokalt/vast/mustafas-kunskaper-raddar-sekelskiftesrenovering-i-skara.

"Consideration of reports submitted by States parties under article 9 of the Convention Twentysecond and twenty-third periodic reports of States parties due in 2016. Sweden.” Refworld. Accessed December 22, 2019. https://www.refworld.org/cgibin/texis/vtx/rwmain?page $=$ country\&docid $=59789 f 3$ f 4 \&kip $=0 \&$ publisher $=$ CERD\& coi $=$ SWE\&querysi $=\% 20$ Sweden \&searchin=fulltext\&sort=date.

Daham, O., L. Asmar, and M. Flygt. "Ordförande Leif Östling lämnar Södertälje science park efter kritiserat uttalande." SVT, October 31, 2019, https://www.svt.se/nyheter /lokalt/sodertalje/leif-ostling-lamnar-sodertalje-science-park.

Ekengren Oscarsson, H. Väljare är inga dumbommar, 2013. Accessed December 17, 2019. https://www.henrikoscarsson.com/2013/12/valjare-ar-inga-dumbommar.html.

Engellau, Patrik. Invandring och brottslighet - ett trettioårsperspektiv. Det goda samhället, 2019. https://detgodasamhalletdotcom.files.wordpress.com/2019/06/rapport-om-invandringoch-brottslighet.pdf.

Eriksson, H. Knutson, M. "Löfven: Unga pojkar ska vara i skolan." SVT, August 30, 2019, https://www.svt.se/nyheter/inrikes/statsminister-stefan-lofven-om-valdsspiralen.

"Ett utvidgat straffrättsligt skydd för transpersoner m.m." Betänkande av Utredningen om transpersoners straffrättsliga skydd m.m., SOU 2015:103, Stockholm 2015.

Fallenius, K. "Östling intervjuades av sajt med kopplingar till vit makt-miljö — Godner (S) kritisk." SVT, October 30, 2019, https://www.svt.se/nyheter/lokalt/sodertalje/leif-ostlingstallde-upp-i-intervju-pa-sajt-med-kopplingar-till-vit-makt-miljon.

"Får man säga 'förorten'? \#pkdebatt om politiskt korrekt språk Del 1.” Accessed December 28, 2019. https://www.youtube.com/watch? $\mathrm{v}=$ bhveFcVdFrc.

Farran-Lee, L. "Granskningnämnden fäller inslag om rasprofilering i TV4: 'Uppenbart kränkande'.” SVT, September 16, 2019, https://www.svt.se/kultur/granskningnamndenfaller-inslag-om-rasprofilering-i-tv4.

Gravlund, W. "Begränsad rätt till tolk i Helsingborg utreds — kan vara lagbrott." SVT, October 14, 2019, https://www.svt.se/nyheter/lokalt/helsingborg/nu-utreds-begransad-ratt-till-tolk-ihelsingborg-kan-bli-ett-lag.

Gravlund, W. "Invandrarnas samorganisation: Börja med att se över sfi." SVT, October 14, 2019, https://www.svt.se/nyheter/lokalt/helsingborg/helt-fel-vag-att-ga-om-fler-ska-lara-sig-svenska.

Gustafsson, A., and G. Adam. "Polisen sökte efter försvunnen 9-årig pojke i Göteborg." SVT, July 15, 2019, https://www.svt.se/nyheter/lokalt/vast/polisen-soker-efter-forsvunnen-9-arigpojke-i-goteborg.

Gustafsson A. "Projekt ska granska salafism i Sverige." SVT, August 5, 2019, https://www.svt.se/nyheter/lokalt/vast/projekt-ska-granska-salafism-i-sverige.

Habte, K. "Varför får inte vi plats i den här debatten?" SVT, August 16, 2019, https://www.svt.se/opinion/ksanet-habte-varfor-far-inte-vi-plats-i-den-har-debatten.

Hallin, G. "Avesta kommun vill få fler företag att anställa nyanlända: 'Går miste om kompetens'." SVT, August 7, 2019, https://www.svt.se/nyheter/lokalt/dalarna/avesta-jobbarmed-projekt-for-att-forandra-attityden-kring-nyanlanda-inom-kommunen.

Hambraeus, U. "Rasbegreppet ska bort ur lagen." SVT, July 30, 2014, https://www.svt.se/ nyheter/inrikes/rasbegreppet-ska-bort-ur-lagen

Hammarstedt, M. "Uppdrag gransknings reportage borde inte förvåna någon." SVT, August 29, 2019, https://www.svt.se/opinion/uppdrag-gransknings-reportage-borde-inte-forvana-nagon.

Hedström, M. "Narkotikahandel och utpressning skakar Jordbro centrum." SVT, October 29, 2019, https://www.svt.se/nyheter/lokalt/stockholm/polisen-oroad-for-utvecklingen-i-jordbro.

Johansson, Birgitta, ed. Miljonprogrammet - utveckla eller avveckla? Stockholm: Formas Fokuserar, 2012.

Johansson Heinö, A. "Heinö: SVT:s språkråd är inget att ta efter.” Borås Tidning, March 21, 2016, http://www.bt.se/ledare/heino-svts-sprakrad-ar-inget-att-ta-efter/. 
Johansson, L. "Krabbfiske - en av många vägar till förortstjejernas integration.” SVT, July 19, 2019, https://www.svt.se/nyheter/lokalt/vast/krabbfiske-en-av-manga-vagar-till-forortstjejernasintegration.

Jönsson, H. “Åklagaren: Ostraffad kvinna nyckelspelare i massiva knarkhandeln.” SVT, October 9, 2019, https://www.svt.se/nyheter/lokalt/vast/huvudprofilen-i-knarkatalet.

Kangasharju, J., and M. Brändström. "Här väljer tre av fyra flyktingar att stanna." SVT, October 16, 2019, https://www.svt.se/nyheter/lokalt/vasterbotten/har-valjer-3-av-4-flyktingar-attstanna-kanns-helt-fantastiskt-storuman.

Karam, S. "Om SD inte är främlingsfientligt — vad är då främlingsfientlighet, enligt Sveriges Radio?” SVT, October 22, 2019, https://www.svt.se/opinion/om-sd-inte-ar-framlings fientligt-vad-betyder-da-framlingsfientlighet-enligt-sveriges-radio.

Klintevall, M. "Ulf Kristersson (M): Begränsa rätten till tolkhjälp." SVT, July 1, 2019, https://www.svt.se/nyheter/inrikes/presstraff-med-ulf-kristersson-i-almedalen.

“Kränkande uttalande i TV4.” Accessed December 28, 2019. https://www.mprt.se/ sv/nyhetsrum/pressmeddelanden/2019/krankande-uttalande-i-tv4/.

Laddade ord i medierna. Sveriges Radio. Accessed November 27, 2019. https://sverigesradio.se $/$ sida/artikel.aspx ?programid $=1650 \&$ artikel $=6505262$.

Lagercrantz, A. "Nya språkråd för att bättre spegla hela Sverige." SVT, December 16, 2015, https://www.svt.se/svt-bloggen/post/nya-sprakrad-att-battre-spegla-hela-sverige/.

Lång, E. "Asylsökande på hal is - testar skridskoåkning för första gången.” SVT, July 26, 2019, https://www.svt.se/nyheter/lokalt/norrbotten/asylsokande-pa-hal-is-testar-skridskoakningfor-forsta-gangen.

Larsson, Y. "Kvinnliga politiker sluter upp bakom Meghan: 'Vi står vid din sida'." SVT, October 20, 2019, https://www.svt.se/nyheter/utrikes/kvinnliga-politiker-sluter-upp-bakom-meghanvi-star-vid-din-sida.

Ljunggren, P. "Socialtjänsten placerade Hassan hos kriminell med långt brottsregister." SVT, September 18, 2019, https://www.svt.se/nyheter/granskning/ug/socialtjansten-placeradehassan-hos-kriminell-med-langt-brottsregister.

Lorentz, E. "Katerina Janouch testar: Tesked i trosan fungerar inte för att signalera om tvångsgifte." SVT, June 17, 2018, https://nyheteridag.se/katerina-janouch-testar-tesked-itrosan-fungerar-inte-for-att-signalera-om-tvangsgifte/.

Lorentz, E. "Nästan inga tvångsäktenskap leder till åtal.” SVT, June 18, 2018, https://nyheteridag.se/nastan-inga-tvangsaktenskap-leder-till-atal/.

Lövfenberg, J. "Regeringen svarar på avhoppen med eget åtgärdsprogram.” SVT, September 21, 2019, https://www.svt.se/nyheter/inrikes/regeringen-svarar-pa-avhoppen-med-eget-atgardsprogram.

Makboul, L. "Alex Schulman: Aldrig sett en kommunperson så nedslagen." SVT, August 28, 2019, https://www.svt.se/nyheter/granskning/ug/alex-schulman-aldrig-sett-en-kommunperson-sanedslagen.

Makboul, L. "Arbetsförmedlingen: Finns inga jobb för utrikesfödda analfabeter." SVT, August 28 2019, https://www.svt.se/nyheter/granskning/ug/arbetsformedlingen-finns-inga-jobb-forutrikesfodda-analfabeter.

Makboul, L. "Jim från Filipstad försöker uppvigla kommuner mot staten.” SVT, August 28, 2019, https://www.svt.se/nyheter/granskning/ug/jim-fran-filipstad-forsoker-uppvigla-kommunermot-staten.

“Män och kvinnor lika arbetslösa." July 15, 2019. Accessed December 17, 2019. https://www.svt.se/nyheter/snabbkollen/man-och-kvinnor-lika-arbetslosa.

Markle, M. "Meghan Markle: I'm More Than An 'Other'." Elle, December 22, 2016, https://www.elle.com/uk/life-and-culture/news/a26855/more-than-an-other/.

Nilsson, J. "Mormor dömd för äktenskapstvång mot flicka: 'Måste antingen giftas bort eller dödas'." Nyheteridag, February 6, 2019, https://nyheteridag.se/mormor-domd-foraktenskapstvang-mot-flicka-maste-antingen-giftas-bort-eller-dodas/.

Nilsson, J. "Pappa gripen i Göteborg - misstänks ha gift bort 14-årig dotter i Palestina." Nyheteridag, June 29, 2019, https://nyheteridag.se/pappa-gripen-i-goteborg-misstanks-hagift-bort-14-arig-dotter-i-palestina/. 
Öberg, Jonas, and Klara Hradilova Selins. Dödligt våld i Sverige 1990-2017. Omfattning, utveckling och karaktär. Rapport 2019:6. Stockholm: Brottsförebyggande rådet, 2019.

O'Connor, P. "Samhället är uppbyggt på att dessa poler hålls åtskilda." SVT, July 4, 2019, https://www.svt.se/opinion/hela-vart-samhalle-ar-uppbyggt-pa-att-halla-dessa-poleratskilda.

"Personer boende i Migrationsverkets mottagningssystem 2018." Swedish Migration Agency. Accessed December 29, 2019. https://www.migrationsverket.se/Om-Migrations verket/Statistik/Asyl.html.

Pettersson, M. "Mångfaldsparaden tågade genom Ängelholm.” SVT, August 31, 2019, https://www.svt.se/nyheter/lokalt/skane/mangfaldsparaden-tagade-genom-angelholm.

“Pilotärende när Sölvesborg säger nej till nyanlända." August 14, 2019. Accessed December 14, 2019. https://www.svt.se/nyheter/snabbkollen/pilotarende-nar-solvesborg-sager-nej-tillnyanlanda.

"Publicistklubben." Accessed November 27, 2019. http://www.publicistklubben.se/om-pk/:

"Rapport i SVT fälls för att ha befäst fördomar." Accessed December 28, 2019. https://www.mprt.se/sv/nyhetsrum/pressmeddelanden/2016/rapport-i-svt-falls-for-att-habefast-fordomar/.

Renman, F. "Poliskvinnan sköt hans bror - fick kram i rätten." SVT, October 3, 2019, https://www.svt.se/nyheter/utrikes/hon-skot-hans-bror-ville-krama-henne-i-ratten.

Sarnecki, J., “Kriminalitet.” February 15, 2019. Accessed December 29, 2019. https://www.migrationsinfo.se/valfard/kriminalitet/.

Schüllerqvist, M. "Zlatan: 'Han förstör det jag byggt upp i 20 år'." SVT, October 8, 2019, https://www.svt.se/sport/fotboll/han-forstor-det-jag-byggt-upp-i-20-ar.

Sköldbäck, C., and L. Brattgård. "Zlatan nekar till faktafelet: "Är du säker?" SVT, October 8, 2019, https://www.svt.se/sport/fotboll/zlatan-nekar-till-faktafelet-ar-du-saker.

Smith A. D. The Ethnic Origins of the Nations, Victoria: Blackwell Publications 1988.

Söderlund, A. "Svenskarna häktas för mordförsök i Finland." SVT, August 29, 2019, https://www.svt.se/nyheter/utrikes/svenskarna-infor-ratta-i-finland.

"Sölvesborg utmanar bosättningslagen - hör debatten i Aktuellt." SVT. October 2, 2019. Accessed December 12, 2019. https://www.svt.se/nyheter/inrikes/solvesborg-utmanarbosattningslagen-hor-debatten-i-aktuellt.

Statistics Sweden (Statistiska centralbyrå). Accessed December 29, 2019. https://www.scb.se/hittastatistik/sverige-i-siffror/manniskorna-i-sverige/sveriges-befolkning/.

Statistics Sweden (Statistiska centralbyrå). Accessed December 29, 2019. https://www.scb.se/hitta-statistik/sverige-i-siffror/manniskorna-i-sverige/utrikes-fodda/.

Sundgren, P. "Utsatta områden har inte tillkommit av en slump." SVT, July 7, 2019, https://www.svt.se/opinion/utsatta-omraden-har-inte-tillkommit-av-en-slump.

Sund, J. "Muskelsjuka Kjell älskar hemtjänsten: 'Det är änglar allihopa'." SVT, September 28, 2019, https://www.svt.se/nyheter/lokalt/vast/muskelsjuka-kjell-alskar-hemtjansten-det-aranglar-allihopa.

"Svensk kvinna gripen för terrorbrott." SVT. July 5, 2019. Accessed December 17, 2019. Accessed December 22, 2019. https://www.svt.se/nyheter/snabbkollen/svensk-kvinnagripen-misstankt-for-terrorbrott-pa-gatwick-flygplatsen.

SVT:s nyheter ska vinklas med eget språk. Accessed November 27, 2019. http://www.xn--fjllsjcua2m.nu/media/20170330-svts-nyheter-ska-vinklas-med-eget-sprak-0.php.

Szwedzka ustawa antydyskryminacyjna: Diskrimineringslagen 2008: 567.

Szwedzka ustawa o radiofonii i telewizji: Radio- och tv-lag 2010: 696.

"Tips och språkråd när du jobbar med att spegla Sverige — fokus mångfald, arbetsdokument Sverigespegling version 20161014." Accessed November 20, 2019. http://www.svtstatic.se /image-cms/svtse/1476689471/svt-bloggen/article10673639.svt/BINARY/Tips\%20och\%20 språkråd\%20reviderad\%20oktober\%202016.

“Topp100 2019: Här är årets 5 bästa nyhetssajter.” Topp100. Accessed November 20, 2019. https://topp100.idg.se/2.39772/1.715014/topp100-2019-nyheter.

“Tre politikområden i fokus för Moderaterna." SVT. October 19, 2019. Accessed December 15, 2019. https://www.svt.se/nyheter/inrikes/tre-politikomraden-i-fokus-for-moderaterna. 
"Uppgift: Svenskiransk forskare kan stå inför avrättning." SVT. August 2, 2019. Accessed December 28, 2019. https://www.svt.se/nyheter/utrikes/uppgift-djalali-kan-sta-infor-avrattning. Utsatta områden - Social ordning, kriminell struktur och utmaningar för polisen. Stockholm: Nationella operativa avdelningen, 2017.

Willander, Erika. Sveriges religiösa landskap - samhörighet, tillhörighet och mångfald under 2000-talet. Stockholm: Myndigheten för stöd till trossamfund 2019.

Zachrisson L. "Mikael Damberg: 'Vi bjuder in alla partier utom SD till samtal'." SVT, September 1, 2019, https://www.svt.se/nyheter/inrikes/debatt-ulf-kristersson-m-och-mikael-damberg-som-gangvaldet.

\section{HOW TO SPEAK ABOUT IMMIGRANTS AND REFUGEES? QUANTITATIVE AND QUALITATIVE ANALYSIS OF ARTICLES PUBLISHED ON SWEDISH PUBLIC-SERVICE TELEVISION'S NEWS SITE}

According to the Swedish Migration Agency (Migrationsverket), in 2015 Sweden received more refugees per capita than any other European country (registered number 181,890). In the year of a European immigration crisis, almost 163,000 people sought asylum in this country. In 2018 there were still over 52,000 people registered entering the country by the Migration Agency. At the end of 2019, when this article was written, in Sweden, a country with a population of a little over 10 million, almost 2 million inhabitants were born outside the country. It is obvious that the question of immigration and refugees has received broad media coverage, it becoming a challenge to speak about these issues in the news without prejudice and stereotypes. In 2016, Swedish public-service television SVT was found guilty by the Swedish Press and Broadcasting Authority when a reporter covering a school attack in the Trollhättan municipality described the victims as "not completely Swedish" (inte helsvenska) judging by their appearance (this is how the attacker chose them). There are other examples of these kinds of cases in which SVT or other stations were found guilty. In those cases, Swedish Press and Broadcasting Authority based their criticism on a paragraph in Swedish Radio and Television Law that asserts "television's particular impact." In light of this development, it became clear that the journalists in publicservice media needed some kind of regulations or guidelines concerning the use of language. In 2015, Anne Lagercrantz, an executive at Swedish public service television's News Division, published an internal document consisting of language advice meant to make news coverage more inclusive. The advice for the employees included e.g. avoiding generalizations about ethnic groups, areas or religions. The purpose of this paper is to present how the SVT document is applied four years later and what language is used in news articles published on svt.se (public service television's news site). Using elements of media discourse analysis of relevant articles on svt.se from 2019 as well as quantitative analysis, the paper will consider the language choices therein from a cultural and media perspective as well as some relevant themes and contexts. The aim of the quantitative analysis is to research how the recommended words and phrases are used in relation to those that are not recommended. Through qualitative analysis, I would like to explore whether the use of the document helps the quest of inclusion and diversity or if it was just News Division's PR reaction to being penalized.

KEY WORDS: immigration, refugee crisis, Sweden, public-service media, news

\section{JAK MÓWIĆ O IMIGRANTACH I UCHODŹCACH? ILOŚCIOWA I JAKOŚCIOWA ANALIZA ARTYKULÓW OPUBLIKOWANYCH NA STRONIE INTERNETOWEJ SZWEDZKIEJ TELEWIZJI PUBLICZNEJ}

Według Szwedzkiej Agencji Migracyjnej (Migrationsverket) w 2015 roku Szwecja przyjęła najwięcej uchodźców per capita ze wszystkich krajów europejskich (zarejestrowana liczba to 181 890). Pod koniec 2019 roku, kiedy powstawał niniejszy artykuł, W Szwecji, kraju o populacji nieco ponad 10 milionów, prawie 2 miliony obywateli urodziło się poza krajem. Oczywiste jest więc, że kwestia imigracji i uchodźctwa jest szeroko omawiana w mediach, dla 
których wyzwaniem stało się poruszanie tych zagadnień bez uprzedzeń i stereotypów. W 2016 roku szwedzka telewizja publiczna SVT została ukarana przez Szwedzką Radę Mediów, kiedy reporter relacjonujący atak nożownika w szkole w gminie Trollhättan opisał ofiary jako ,nie do końca Szwedów” (inte helsvenska), oceniając ich na podstawie wyglądu. W związku z tego rodzaju sytuacjami kierownictwo działu informacyjnego szwedzkiej telewizji publicznej uznało, że dziennikarze potrzebują wskazówek dotyczących języka używanego w prowadzonych relacjach i artykułach. Powstał wewnętrzny dokument, w którym przedstawiono porady językowe, m.in. zalecenia dotyczące unikania generalizacji dotyczących grup etnicznych, regionów i religii. Celem niniejszego artykułu jest przedstawienie, w jaki sposób dokument SVT był stosowany w 2019 roku i jaki język jest używany w artykułach publikowanych na stronie informacyjnej svt.se. Przy zastosowaniu wybranych elementów analizy dyskursu oraz analizy ilościowej $\mathrm{w}$ artykule przedstawiono wybory językowe dziennikarzy $\mathrm{z}$ perspektywy kulturowej i medioznawczej. Celem analizy ilościowej jest wykazanie częstotliwości korzystania z zalecanych słów i zwrotów w relacji do tych, które nie są zalecane. Analiza jakościowa ma sprawdzić, czy dokument pomaga $\mathrm{w}$ dążeniu do różnorodności i integracji, czy też zalecenia to jedynie działanie mające na celu poprawę wizerunku.

Słowa kluczowe: media publiczne, Szwecja, imigranci, uchodźcy, poprawność polityczna 